\title{
TOWARDS PROGRAMME IMPROVEMENT IN NON-FORMAL VOCATIONAL EDUCATION AND TRAINING IN MOZAMBIQUE
}

\author{
Alzira Manuel \\ Eduardo Mondlane University, Maputo, Mozambique \\ E-mail: alzira@uem.mz \\ Oleg Popov \\ Umeå University, Umeå, Sweden \\ E-mail: oleg.popov@umu.se \\ Domingos Buque \\ Eduardo Mondlane University, Mozambique \\ E-mail: domingos.buque@uem.mz
}

\begin{abstract}
The current situation of Mozambique, characterized by limited but highly needed Formal Vocational Education, demands the development and improvement of Non-formal Vocational Education and Training (NFVET). NFVET can provide relevant knowledge and skills, particularly for out of school and unemployed youth and adults to promote social inclusion and development. This is a qualitative case study with some elements of action research. Semi-structured interviews with six educators, classroom observations and two focus group interviews with former participants were implemented. The research aims to explore ways by which NFVET programmes can be improved in order to increase people's chances, not only to get work, but also to be able to participate actively in their own process of development. The findings suggest some directions for the improvement of NFVET in Mozambique in order to empower people to actively participate in the social and economic life of their local communities and broader society.
\end{abstract}

Key words: empowerment, life skills, non-formal vocational education, social inclusion.

\section{Introduction}

According to the Ministry of Education (2011), the major challenges of the educational sector in Mozambique are related to access, quality and the administrative system. Research on both formal and Non-Formal Vocational Education and Training (NFVET) for youth and adults in Mozambique raised concern about the effectiveness of the programmes. According to Brower, Brito and Menete (2009, p. 284), the poor quality of many vocational education and training programmes in the country has a negative impact on the "chances of employability of the learners". Pinto (2010) noted the lack of alignment between the demands of the labour market and the curriculum provided in many training centres. Similarly, the study of Van der Linden and Manuel (2011) found that some of these programmes are poorly aligned with the experience of the participants. When Caifaz (2012) analysed the outcomes of four training centres in Mozambique, he could estimate that the employment rate of the graduates was $35 \%$ of which $9 \%$ was self-employment. Thus, previous research revealed that NFVET programmes provide limited help to youth and adults to deal effectively with the demands of social and economic life. 
Alzira MANUEL, Oleg POPOV, Domingos BUQUE. Towards programme improvement in non-formal vocational education and training in Mozambique

EMS

OF EDUCATION

IN THE $21^{\text {st }}$ CENTURY

Volume 67,2015

The purpose of this research was to explore how NFVET programmes can be improved to enhance people's chances to get work and to participate actively in their own process of learning and development. It is guided by the following research questions: How do educators and participants understand the importance of the courses of NFVET? What are the characteristics of the activities of NFVET in the selected training programmes? How can NFVET programmes be improved?

\section{Research Problem}

Non-Formal Vocational Education and Training (NFVET) in Mozambique is considered to be one of the ways of improving access to education for youth and adults who lack both schooling and vocational skills. According to Grandstaff (1978, p. 117), "Non-Formal Education shows strong potential for getting at the human condition of those most likely to be excluded from formal schools, the poor, the rural, the illiterate, the unemployed..." In Mozambique, governmental, non-governmental, religious organizations and private institutions are engaged in different initiatives of Non-Formal Vocational Education and Training. However, the quality and effectiveness of some programmes is rather poor. In this sense, it is relevant to explore how NFVET programmes can be improved.

\section{Research Focus}

Non-Formal Vocational Education and Training is seen as a way to empower people, particularly out of school and unemployed youth and adults (Yassunaga, 2014). It can help especially those who are excluded from formal education to acquire knowledge, skills, values and attitudes to improve their lives. Different studies have aimed to investigate the factors that can contribute to the effectiveness of NFVET programmes. Tukundane and Blaak (2010) refer to the need for guidance, counselling for the learners and partnerships between the training institutions and the key stakeholders. At the macro level they point out the need for appropriate policies which can support the training initiatives. Among the different factors identified that can contribute to an increase in the effectiveness of NFVET, Nampota (2010) identified the need for administrative strategies such as control of the training activities including the establishment of a system responsible for monitoring the implementation of the programme ensuring that programme goals are being met. This author also argues that shared ownership between the government and the community is important, to ensure "attendance and the provision of teaching and learning resources" (Nampota, 2010, p. 238). Teaching and learning resources constitute one of the great constrains in NFVET and impact the objective of the training.

The effective NFVET is also seen as providing a combination of "practical marketable skills with life skills" (Blaak, Openjuru \& Zeelen, 2013, p. 95), aiming to empower participants. Singh, (2003) describes life skills as follows:

"Life skills defined in a general way mean a mix of knowledge, behaviour, attitudes and values and designate the possession of some skill and know-how to do something, or reach an aim. They include competencies such as critical thinking, creativity, ability to organise, social and communication skills, adaptability, problem solving, and ability to cooperate on a democratic basis" (p. 4.)

Life skills are functional capacities that can allow people to achieve their objectives. According to Johnson \& Ganesh (2012), life skills empower people to actively participate in the economic and social activities of their communities and societies, as they "are the abilities and behaviour that enable individuals to deal effectively with the demands and challenges of every- 
day life" (p. 1). Thus, effective NFVET programmes should aim not only to provide knowledge

day life" (p. 1). Thus, effective NFVET programm
and skills, but also to empower the participants.

Empowerment highlights education which emphasizes "ownership of the learning process and learning to acquire the skills to actively promote changes [...] rather than becoming passive recipients of top-down initiatives" (Preece, 2009, p. 66). A concrete example of the empowerment of teachers working in vocational health education programmes in Mozambique is described by Mauaie, Ito \& Arroio (2014):

"The practice of empowerment is fundamental to free up teachers from the vice of centralised decisions, which make change slow and bureaucratic. In this way they can become more autonomous, they are able to develop materials according to their needs supported by simple equipment such as a personal computer and digital camera. In this perspective, they are producers of content, not just consumers, they are able to access, analyse and choose what they need.” (p 121.)

Further, they make a general conclusion, that "the empowerment of teachers is an important and crucial aim that it is necessary to keep in mind for developing countries" (Mauaie, et al. 2014, p. 122).

These issues also find justification in the theoretical considerations presented below.

\section{Theoretical Considerations}

As the world is constantly changing, education and training need to act in order to respond and to promote changes within societies (Jarvis, 2006). Educators are challenged to find appropriate methods which can help people to be more active and participative in the wider environment of their individual and collective life. This emphasizes the role of educators as facilitators. According to Jarvis (2006), the role of educators as facilitators is to "help learners to both learn their subject and achieve their potential" (p. 25). The facilitation of knowledge and skills moves education from the provision of "static knowledge to a dialogical relationship where knowledge is co-created (Jarvis, 2006, p. 99).

'Educators as facilitators' is the foundational concept of Freire's pedagogy in which participative learning is at the core. Freire also recognizes the empowering character of the dialogue. Accordingly, dialogical relations are needed to allow "actors to cooperate in perceiving the same cognizable object” (Freire, 2005, p.72). Freire rejects 'banking education' in which learners are simply receptacles of knowledge. He argues the need for learner-centred learning, in which the educator is the facilitator of knowledge instead of narrator. For Freire, education should empower the learners, to be able to recreate the knowledge not to passively repeat the acquired information.

Participative learning leading to the learner's empowerment is of vital importance. In the context of this research, participative learning and empowerment can be viewed as a way to improve the self-esteem of the participants of NFVET as many of them are excluded both from education and from employment.

\section{Methodology of Research}

\section{General Background of Research}

The research has a qualitative exploratory character with some elements of action research applied in two case studies. Qualitative research is based on the interpretation of the phenomena focusing on the reality and the meaning that people give it. According to Ritchie and Lewis (2008) "qualitative research emphasizes and values human interpretative aspects of knowing about the social world and the significance of the investigator's own interpretation and understanding of the phenomena being studied." (p. 7) 
Alzira MANUEL, Oleg POPOV, Domingos BUQUE. Towards programme improvement in non-formal vocational education and training in Mozambique

OF EDUC

PROBLEMS

IN THE $21^{\text {st }}$ CENTURY

Volume 67,2015

Action research emphasized participatory and collaborative ways of knowledge production and encouraged participants to act as "collaborators in the research rather than being subjects of it" (Denscombe, 2003, p. 74). According to Koshy (2010) "action research is an enquiry where participants and researchers co-generate knowledge through a collaborative communicative process." (p. 21). Following the participatory nature of the action research approach, a feedback group was created. The main purpose was to gain insight into the participant's reflection and allow their collaboration during the research process.

\section{Research Sample}

The research was conducted in two non-governmental organisations providing NFVET in peripheral Maputo, Mozambique. One of them belongs to a Christian congregation, this organisation is also responsible for the design of the training programme. The second organisation was created by an association of farmers and endorsed by the National Institute of Employment and Professional Training, which also approved its curriculum. These organisations were selected purposively from the list of NFVET providers in peripheral Maputo. The selection was based on criteria of being rather successful according to the coordinator of NFVET from the National Institute of Employment and Professional Training. According to him, these organisations are renowned as providers of vocational training for out of school youth and unemployed adults for many years. The sample is composed of twenty one respondents consisting of six educators and fifteen former participants who were involved in two focus group sessions. The six educators were selected from a total of ten educators working with vocational courses in both centres. Purposive sampling was used for the selection of both educators and former participants, on the principle that they possess knowledge and experience in relation to the topic of the research and would give valuable contributions.

\section{Instrument and Procedures}

Concerning data collection, the research used semi-structured interviews, observation, focus groups and also took into consideration data from a workshop prepared within the framework of action research methodology. The research has been designed to be implemented in four steps: observation of professional practices, critical reflection, systematic enquiry, and planning for action (Castello, 2007, p. 11).

The workshop, which took place in February, 2012 at Eduardo Mondlane University, marked the beginning of the systematic enquiry step. This workshop focussed on collective reflection about NFVET programmes and the collection of ideas about how these programmes can be improved. After a general discussion, the participants were organized in small groups composed of programme coordinators, educators, learners from the training centres and students from the Master programme in adult education, to reflect on ideas for programme improvement. The objective was to collect suggestions about how to improve NFVET from the perceptions of different actors. The participants wrote down their contributions, which were collectively discussed in the workshop and later evaluated in the feedback group. This group was established to allow collective and participatory reflection during the different steps of the research process.

In the feedback group two programmes were selected for further research and semistructured interviews were conducted with six educators in the programmes selected. The interview guide was pre-tested with three educators at one of the NFVET centres in Maputo, to ensure clarity of its content. Non-participant classroom observations were also used to understand the characteristics of the teaching-learning activities in the selected training centres. The focus was on the role of educators and learners during the training process. 
Two focus group interview sessions with former-participants were organized. According to Creswell (2008), focus group interviews allow the collection of common understanding from several individuals as well as views from specific people. The focus group interviews aimed to collect the perceptions of former-participants about the training programmes and their suggestions concerning the factors that can contribute to the improvement of NFVET programmes. The data gathered from the semi-structured interviews and the focus group interviews were digitally recorded and transcribed into word format.

\section{Data Analysis}

For the data analysis, the transcribed data and the data from workshop, were systematically read, aiming to understand what is being said and to make sense of the data. As Liamputtong (2009) advises, the researchers need to analyse the transcript to capture the sense of the data. In this process the codes were inductively created. Analysis of the transcriptions was also supported by the data from classroom observation. The data was continually interpreted through the process of constant reading and analysis, resulting in the generation of the themes. The preliminary findings were presented and discussed in the second workshop with different practitioners of adult education and NFVET in 2014. In this workshop both categories of main respondents were represented.

\section{Ethical Considerations}

The programme coordinators in the training centres were contacted, the objectives of the research were explained to them, and they were asked about their willingness to collaborate. After their acceptance, they informed the educators and the learners of the reason for the presence of the researcher in their organisation. The schedule for data collection was designed in collaboration with the programme coordinators, with the consent of the educators. When collecting data, the main researcher clarified the objectives of the interview for the respondents and asked about their willingness to participate. The names of the organisations and the names of the respondents were anonymised.

\section{Results of Research}

The findings are presented in the following three paragraphs corresponding to the issues raised by the research questions of the study.

\section{The Importance of the Courses in Non-Formal Vocational Education and Training}

The courses provided in NFVET centres are considered to be a way to the world of work. The educators interviewed consider that the courses result in work opportunities in the formal and informal sector. For example, with the skills of car-repair "individuals can work in different settings, even in the streets, because nowadays there are many cars in Maputo", explained one of the respondents. This kind of work in Mozambique is called 'biscato', meaning people work only when they are asked by an occasional customer; it is different from self-employment as there is no need to acquire any authorisation from the local municipal authority.

The informal sector was seen by the educators as the most probable place for the graduates to work. The services delivered by the informal sector are usually preferred by people who do not have enough money to pay for more expensive services in the formal sector. According to one of the educators, "it is easy to work informally, the clients look for cheaper places where they can repair their cars". Services in the informal sector are usually cheaper than in 
Alzira MANUEL, Oleg POPOV, Domingos BUQUE. Towards programme improvement in non-formal vocational education and training in Mozambique

OF EDUC

PROBLEMS

IN THE $21^{\text {st }}$ CENTURY Volume 67,2015

66 the formal sector because there are less or no taxes paid. Some former participants share similar perceptions with the educators. They believe that there will be job opportunities after this training, one of them argues that, "...people can work at home, there are always people asking for help" (car-repair). Other former participants confirmed that the courses "make it possible to gain money because people can work in a company and... simultaneously can work at home..."

Former participants brought up another aspect concerning the value of the training. They see it as a way of acquiring a certificate, as one of the respondents said, "the training allows us to get a certificate to enter the companies....many people do this activity in the streets ...they have practice, but they cannot enter the formal job market without a certificate." In fact, a certificate is one of the main requirements asked for by employers. It is one of the reasons why many youth and adults join short-term training. It allows a person to get a certificate in a short period of time and be able to look for employment. One of the educators added another relevant aspect, expressed in terms of scarcity of skilled people in the area participants are trained for. In his words, "the market lacks technicians in refrigerating in quality and quantity..."

Educators in the area of small business management believe that the skills that the learners acquire can be useful for a wide range of private activities, "If we intend to encourage the learners to implement self-employment, small business management is needed". In this centre, participants from different courses (car-repair, electricity and refrigeration) attend the small business management course at the end of their training. In summary, NFVET is seen as leading to occasional work, self-employment and formal jobs.

\section{Teaching and Learning Activities}

Answering the question "How do you usually teach in your classes?" some educators highlighted a participatory way of teaching, "In general I use different teaching methods, with a particular attention to interaction with the learners". Another educator explained, "...my classes are purely participatory. The idea is that knowledge is elaborated together with the learners, but as they are not familiar with this method they found it strange ..." This educator has also been influenced by his main activity of community development, where he uses a participatory approach.

However, classroom observations showed that the majority of the classes are lacking the participative approach. The classes are predominately based on dictation or writing down the content from the blackboard. The learners are usually seated in rows transcribing what has been written down on the blackboard. Some days later, the teachers check the learners' understanding of the contents through a written test. Sometimes it is multiple choice, where learners do not have much chance to communicate their reflections about the topic. This checking phase is followed by 'practical' exercises, which are also theoretical because of a shortage of equipment. Some instruments and tools that educators teach about are drawn on the blackboard and the learners try to reproduce them in their exercise books. An ex-participant complained: "It was difficult to understand what the educator had drawn on the blackboard; there were no real instruments available in the training centre..."

Thus, most of the lessons are theoretical, and educator-centred. Justifying the inadequate practical part of the training, the educators refer to the lack of equipment. The issue of lack of or outdated equipment came up very often in the focus groups sessions. The meetings revealed that learners were aware of the gap between what they learn in the training centre and their experience during the internship, "the equipment and contents are out of date; when we are at the internship it is difficult to do the work well, as we have not been trained in a practical way..."

In the case of the sewing course, the practical part is delivered in a much more participa- 
tory way and here the learners have time to interact with the educator and amongst themselves. Concerning the practical activity, each learner is free to decide what she/he wants to do as a practical exercise or as a final assignment. The educator stimulates the most skilled learners to interact with those who have learning problems. In this case the training programme does not include internship, but due to extensive practice, interaction and exchange of experience during the learning process, the learners seem confident with their practical exercises. This can be seen in this statement, "the training made me understand the basics of sewing, I think that after practising I will further improve my activity".

\section{Ideas for Programme Improvement}

The ideas for programme improvement were closely linked to the barriers that educators and learners perceive in the teaching-learning process. Some of the suggestions are related to pedagogical aspects of the training, such as: the provision and improvement of teaching and learning materials, improvement of the curriculum, and improvement of the educators' competencies. Referring to competencies, one of the educators observed that "...the improvement of educators' competencies could be achieved by a short-term training or by the exchange of experiences with other training centres..." Another participant suggested that "The class must be participatory, to guide the learners to think and come up with solutions..."

The need for teaching material was also emphasized by the ex-participants in the focus group sessions. They suggested that "... it is necessary to improve the learning materials, for instance the manuals." The data from observation showed that the learner's manuals are of poor quality. The contents are out of date and the pictures are not clear. In general, concerning the curriculum, educators and ex-participants perceived that the curriculum needs to be reviewed, "It is necessary to revise the curriculum... because it is old ...the contents should be updated."

Referring to the learners, one of educators suggested that "...the required schooling level of the learners here should be revised to ensure quality..." The learners' previous schooling has been pointed out as one of the constraints in the teaching process, particularly in the courses such as car-repairing, electricity and refrigeration, which demand a large degree of general knowledge.

The need for the improvement of NFVET is also seen in terms of increased partnership or connections with the labour market, as one of the ex-participants suggested "...the training centre needs to cooperate with the labour market even in the informal sector to understand the opportunities available." The former participants also called for more creativity from the learners. They suggested that "...the learners need to see the training not only as an activity between the training centre and the internship, but they must check other ways... within their communities. Meet people who are working in the same activity and ask for help to improve their practices..." The ex-participants acknowledged the important role of informal learning in people's everyday lives.

In summary, the factors for programme improvement, according to the respondents are: improvement of the curricula, improvement of teaching and learning materials, improvement of educators' competencies, revision of the schooling level of the learners required for participation in the training (this is related to the courses leading to the industrial sector), enhancement of partnerships between the training centres and the labour market in both the formal and informal sector, and provision of complementary skills to vocational skills.

These factors for programme improvement identified by the respondents of both the semi-structured interview and the focus group are similar to the factors pointed out by the participants of the workshop. However, two more or less different elements emerged from the participants of the workshop. One of these elements is the sustainability of NFVET. The respondents suggested the involvement of local enterprises and the civil society, arguing that 
Alzira MANUEL, Oleg POPOV, Domingos BUQUE. Towards programme improvement in non-formal vocational education and training in Mozambique

OF EDUCA

PROBLEMS

IN THE $21^{\text {st }}$ CENTURY

Volume 67,2015

"they should give some support to the activity of NFVET and take the subject up in their agenda of social responsibility". The sustainability of NFVET in general has been one of the major problems for the activities of NFVET in Mozambique.

\section{Discussion}

The findings reveal that both educators and former-participants have a positive perception about the importance of the NFVET courses. They consider the courses as a way to the world of work, broadening the opportunity to get formal work, self-employment or some occasional income-generating activities. All these alternatives are useful in the context of Mozambique which is characterized by massive unemployment and poverty.

However, the findings also show that NFVET in the selected organisations is characterized by different limitations related to lack of resources and the dominant traditional teaching methods. The issue of lack of resources, mainly for the practical lessons, influences the skills development of the learners. It is not possible to effectively learn vocational skills without the appropriate practice, especially in courses such as car-repair, electricity, sewing, etc.

The training centres attempt to find some alternatives. For instance, in one of the cases some learners have the opportunity for internship in the factories depending on the availability of vacancies. As they suggested, this makes the learners see other possible opportunities in the informal sector. However, the alternative of training in the informal sector has another constraint, since the learners need certification of their skills, but the informal sector cannot issue such a document.

Concerning pedagogical issues in the training, we found that unfortunately NFVET courses often replicate the model of formal education. The teaching and learning activities in general, are structured in theoretical lessons and written tests. Freire (2005) considers this type of education as 'narrative', in which the learners are receptacles of the learning content. This educator-centred style of teaching promotes learners' passivity and lack of reflective thinking. In the actual context of daily change, education needs to stimulate peoples' functional skills to actively act in different spheres of their lives. This implies a need for profound changes in the roles of both educators and learners in NFVET courses.

Jarvis (2006) suggests that educators must help learners to learn and achieve their potential. This is only possible with participatory learning. Flexibility and learner-centeredness should be basic principles in NFVET. These strategies can help to provide relevant skills to the learners. The ideas for programme improvement show that there is a need for increased governmental attention to the area of NFVET. This is linked to the provision of teaching and learning materials in adequate quantity and quality, the improvement of the curriculum and development of educators' competencies. The need for flexible and relevant curricula is also highlighted in the literature (Tukundane \& Blaak, 2010; Yassunaga, 2014).

The need for external control over the activities of NFVET centres was also considered as an enabling factor for the effectiveness of the programmes. This idea is also shared by Nampota (2010), who not only identifies control, but also monitoring of the training activities. This can help to identify failures during the training process, if possible, to look for timely solutions to increase the chance of the effectiveness of the training.

Another important factor identified is the link between the training centres and the labour market. However, the training programmes also need to consider the social dimensions. Thus, the training activities need to be positioned between the needs of the labour market and the needs of the learners themselves as individuals and social beings. In this perspective, the learning activities need to take into account the learners' learning needs while developing their vocational skills. The learning activities also need to be reinforced by counselling and guidance (Blaak, Openjuru \& Zeelen, 2013). These different efforts and initiatives, according to 
Tukundane and Blaak (2010), need to be embedded in a supportive political environment. This means that the educational authorities need to build appropriate policies that can contribute for the effective development of NFVET.

\section{Conclusions}

This research aimed to explore factors that can contribute to more effective NFVET in Mozambique. The literature reviewed and the methodology used allowed the identification of some of these factors. To get insight into the programmes selected, educators' perceptions about the courses they teach and learners' perceptions about the importance of the skills they learn as well as the characteristics of the teaching and learning activities were explored. These aspects contributed to an understanding of the educators and former-participants' suggestions concerning programme improvement, which constitutes the focus of the research.

The respondents see the courses in NFE as helpful for the world of work. They see the world of work not only as formal jobs but also self-employment or occasional work. This is important in the context of Mozambique in which there are not enough formal jobs for everyone, and the informal sector is one of the major alternatives. The research revealed that NFVET programmes need to be improved. Educators need support to improve the quality of their work, particularly in terms of teaching methods. Collaborative learning in which both educators and learners are active in the process of knowledge construction, is advisable.

The issue of lack of appropriate teaching methods, shortage of teaching and learning materials, and lack of flexibility of the programmes, impacts on the effectiveness of the training programmes. These aspects can serve as a lesson for the institutions linked to education and training to increase their efforts towards increasing the quality of NFVET, as it is seen as one of the ways of expanding access to education and training in the country.

The ideas for programme improvement, according to this research, can be located in three important dimensions: the pedagogical dimension, which embraces flexible and learnerscentred curricula (expressed in terms of improvement of the curricula); appropriate teaching and learning materials (expressed in terms of the provision of adequate teaching and learning materials); ensuring the educators' competencies and providing a supportive environment (expressed in terms of improvement of educators' competencies and professional environment). The administrative dimension, referring to control of the activities in the training centres to increase the probability of an effective implementation of the programmes, is also one of the important factors identified, as well as the establishment of functional partnerships with the labour market including the involvement of local enterprises. However, the political dimension, linked to the policies that can serve as an umbrella for the activities of NFVET, is necessary. These aspects can contribute to learners' confidence, empowerment, and can increase their chances not only in the labour market but also in their participation in the wider social and economic life in their communities and society.

Despite these results, the study has some limitations. One of these limitations is linked to its methodology. It is a case study, which explored the perceptions and ideas of educators and former participants in two organizations; its findings cannot therefore be generalised over the whole country. The sample of this research is rather small. It was limited by the total number of educators working in the training centres and by the number of former participants who it was possible to identify. However, we consider the quality of contributions as representative for these categories of respondents.

Another limitation is related to the action research methodology used. For instance, Denscombe's action research model suggests four steps in this research method: observation of professional practices, critical reflection in which the problem is identified, systematic and rig- 
Alzira MANUEL, Oleg POPOV, Domingos BUQUE. Towards programme improvement in non-formal vocational education and training in Mozambique

OF EDUCATI

IN THE $21^{\text {st }}$ CENTURY Volume 67, 2015

70 orous inquiry and action towards improvement of the practices. These steps can be repeated as a cycle. However, due to time limitations, the action research in this study was only situated in the first three steps, as suggested above. The characteristics of action research were mainly used in terms of the active involvement of the respondents and their collaboration in the process of knowledge production, to a certain extent this contributed to the empowerment of the educators in the selected training centres.

\section{References}

Blaak, M., Openjuru, G., \& Zeelen, J. (2013). Non-formal vocational education in Uganda: Practical empowerment through a workable alternative. International Journal of Educational Development, 33 (1) 88-97.

Brouwer, R., Brito, L., \& Menete, Z. (2009). Educação, formação profissional e poder. In L. Brito, C. Castel-Branco; S. Chichava \& A. Francisco (Eds), Desafios para Mocambique 2010, Maputo: Instituto de Estudos Económicos, 273-296.

Castello, P. (2007). Action research. London: Continuum.

Caifaz, I. (2012). Occupational activities and experiences of graduates of vocational training programmes in Maputo. A tracer study. Master dissertation. Groningen. University of Groningen. Faculty of Behavioral and Social Science.

Creswell, J. (2008). Educational research: Planning, conducting and evaluating quantitative and qualitative research. $3^{\text {rd }}$ ed. New Jersey: Person Education International.

Denscombe, M. (2003). The research guide for small-scale social research projects, $2^{\text {nd }}$ ed. Philadelphia: Open University Press.

Freire, P. (2005). Pedagogy of the oppressed. $30^{\text {th }}$ ed. New York/London: Continuum.

Grandstaff, M. (1978). Non-formal education as a concept. Prospects, 8 (2), 177-182.

Jarvis, P. (2006). The theory and practice of teaching. $2^{\text {nd }}$ ed. London/New York: Routledge.

Johnson, N., \& Ganesh, E. (2012) Life skills of the college students in Puducherry Region. Bilingual Journal of Humanities and Social Sciences, 3 (1), 37-39.

Koshy, V. (2010). Action research for improving educational practice: A step-by-step guide. $2^{\text {nd }}$ ed. London: SAGE.

Liampunttong, P. (2009). Qualitative data analysis: Conceptual and practical considerations. Health Promotion Journal of Australia, 20 (2), 133-139.

Mauaie, C., Ito, L., \& Arroio, A. (2014). Media literacy and health education: Empowering teachers in the Republic of Mozambique. Problems of Education in the $21^{\text {st }}$ Century, 60 (60), 114-124.

Ministry of Education (2011). Strategy of adult literacy and learning in Mozambique 2010-2015. Maputo: Ministry of Education.

Nampota, D. (2010). Development and implementation of non-formal education for early school leavers. In J. Zeelen, D. Nampota \& M. Ngabirano (Eds), The burden of educational exclusion: Understanding and challenging early school leaving in Africa. Rotterdam: Sense Publishers, 225-239.

Pinto, A. (2010). Políticas Nacionais, os Planos Estratégicos da Educação e o Ensino Técnico Profissional em Moçambique. Lisboa: $7^{\circ}$ Congresso Ibérico de Estudos Africanos. Retrieved from https://repositorio.iscte-iul.pt/bitstream/10071/2279/1/CIEA7_8_PINTO_As\%20pol\%C3\%ADticas\%20nacionais.pdf

Preece, J. (2009). Lifelong learning and development. London/New York: Continuum International Publishing Group.

Ritchie, J., \& Lewis (2008). Qualitative research practice: A guide for social science students and researchers. London: SAGE publications.

Singh, M. (2003). Understanding Life Skills. Background paper prepared for the Education for All Global Monitoring Report 2003/4. UNESCO. Retrieved from http://unesdoc.unesco.org/ images/0014/001469/146963e.pdf

Tukundane, C., \& Blaak, M. (2010). Towards new intervention programmes for early school leavers in Uganda. In J. Zeelen, D. Nampota \& M. Ngabirano (Eds), The burden of educational exclusion: Understanding and challenging early school leaving in Africa. Rotterdam: Sense Publishers, 209224

Van der Linden, J., \& Manuel, A. (2011). Beyond literacy: Non-formal education programmes for adults in Mozambique. Compare, 41 (4), 467-480. doi: 10.1080/03057925.2011.581514. 
Alzira MANUEL, Oleg POPOV, Domingos BUQUE. Towards programme improvement in non-formal vocational education and training in Mozambique

PROBLEMS

OF EDUCATION

IN THE $21^{\text {st }}$ CENTURY

Volume 67,2015

Yassunga, M. (2014). Non-formal education as a mean to meet learning needs of out-of school chil71 dren and adolescents. All in School: Out of school children Initiative. UNICEF and UNESCO Institute for statistics. Retrieved from http://allinschool.org/wp-content/uploads/2015/01/OOSC2014-Non-formal-education-for-OOSC-final.pdf.

Advised by Agnaldo Arroio, University of Sao Paulo, Brazil

Received: October 02, 2015

Accepted: October 20, 2015

Alzira Manuel

PhD Student, Lecturer, Eduardo Mondlane University, Julius Nyerere Av. P.O. Box 257, Maputo, Mozambique.

E-mail: alzira@uem.mz

Oleg Popov

PhD, Associate Professor, Umea University, 90187 Umeå, Sweden.

E-mail: oleg.popov@umu.se

Domingos Buque

PhD, Lecturer, Eduardo Mondlane University, Julius Nyerere Av. P.O. Box 257, Maputo, Mozambique.

E-mail: domingos.buque@uem.mz 